\title{
Hydrologic Relationships of a Paired Coastal Watershed on the Santee Experimental Forest for Evaluating Watershed-scale Effects of Longleaf Pine Restoration on Water Yield
}

\author{
Devendra Amatya ${ }^{1}$, Herbert Ssegane $^{2}$, Carl Trettin ${ }^{1}$, and Mohammad Daud Hamidi ${ }^{3}$ \\ ${ }^{1}$ USDA Forest Service \\ ${ }^{2}$ Oshkosh Corp \\ ${ }^{3}$ Durham University
}

October 5, 2020

\begin{abstract}
We analyzed hydrology of 1st order paired watersheds (155-ha WS77 (treatment) and 160-ha WS80 (control)) in anticipation of a study to assess the hydrologic response to restoring longleaf pine (Pinus palustris) on the Santee Experimental Forest in coastal South Carolina. Rainfall, streamflow (runoff), water table, and other watershed parameters measured during 2011-2019 were used as the basis of comparison with earlier studies. The objective is to affirm hydrologic relationships between the two watersheds by testing the hypotheses that the a) mean annual runoff coefficients (ROC) are not different between the pair and b) paired mean annual ROCs, mean monthly runoff difference and calibration regression are not different $(\alpha=0.05)$ from the respective ROCs, runoff difference, and regression reported for historic 1969-1978 and 2004-2011 forest regeneration periods, and c) the calibration regression is also indifferent from both periods and statistically significant $(\alpha=0.05)$. Annual ROCs were not statistically different $(\mathrm{p}>0.17)$ between the WS77 (0.24) and WS80 (0.19) for 2011-2019 and the ROC pair was also not different $(\mathrm{p}>0.20)$ from 2004-2011 (WS77 (0.18); WS80 (0.14)), nor ( $\mathrm{p}>0.8)$ from the 1969-1978 period (WS77 (0.25); WS80 (0.18)). The mean monthly runoff difference (WS80-WS77) of $-7.54( \pm 1.68) \mathrm{mm}$ was not different $(\mathrm{p}=0.41)$ from $-8.57( \pm 1.66) \mathrm{mm}$ for the 1969-1978 period but different from -3.89 $( \pm 1.09) \mathrm{mm}$ for 2004-2011 period. The inherently higher WS77 runoff than WS80 was attributed to its $>$ three times smaller surface storage than WS80 and its land morphological characteristics defined by higher hypsometrical integral. The monthly runoff calibration relationship (WS77 $=1.03^{*}$ WS $80+$ 7.00; R2 $=0.83 ; \mathrm{p}=0.0005$ ), without an extreme October 2015 runoff (outlier), was significantly different $(\alpha=0.05)$ from the historic 1969-1978 relationship, but not from the recent 2004-2011 one with similar climate regime.
\end{abstract}

\section{INTRODUCTION}

Restoration of longleaf pine (LLP) (Pinus palustris ) ecosystems is a public land management objective throughout the southeastern U.S., and a principal goal in the Forest Plan for the Francis Marion National Forest (FMNF) in South Carolina, U.S.A. While there have been numerous plot or stand-scale studies regarding LLP ecology, silviculture, and other ecosystem services (Samuelson, Stokes, \& Johnsen, 2012), there are uncertainties regarding the watershed-scale effects of reestablishing longleaf pine communities due to the spatial heterogeneity of soil conditions, micro-topography, slope, and understory vegetation, which affect soil-water storage. In contrast to loblolly pine (Pinus taeda L.) (LP) stands managed for timber production, LLP stands managed for open canopy conditions with frequent prescribed fire have a much lower stocking, a longer period of open canopy, a sparse mid-story and an understory generally dominated by grasses and sedges, potentially influencing soil moisture and transpiration (Brantley, Vose, Wear, \& Band, 2018). As a result of these differences in stand structure and composition, it may be expected that the LLP stands will exhibit less leaf area, likely less ET and interception loss, and more infiltration of 
rainfall recharging groundwater and increasing runoff than stands managed for timber production, especially LP stands where fire is excluded.

The runoff generation processes on coastal watersheds with shallow WT $(<2-3 \mathrm{~m})$ soils with variable permeability and infiltration rates has been shown to be dominated by saturation excess flow (Eshleman, Pollard, \& O'Brien, 1994; Griffin, Callahan, Vulava, \& Williams, 2014; Slattery, Gares, \& Phillips, 2006; Williams, 2007). The runoff process is complicated by interactions of both forest management and extreme events (Amatya, Williams, Nettles, Skaggs, \& Trettin, 2019; Hornbeck, Adams, Corbett, Verry, \& Lynch, 1993; Kelly, McGuire, Miniat, \& Vose, 2016; Shelby, Chescheir, Skaggs, \& Amatya, 2005). The near-surface or shallow WT, a surrogate of soil water storage regulated by ET (Acharya, Jawitz, \& Mylavarapu, 2012; Amatya, Skaggs, \& Gregory, 1996; Loheide, Butler, \& Gorelick, 2005) drives most streamflow (as shallow surface runoff and drainage) in these shallow coastal systems (Harder, Amatya, Callahan, Trettin, \& Hakkila, 2007). Evaristo and McDonnell (2019)'s finding based on their global analysis that the amount of water stored in a landscape and increased loss of water through ET are the most important factors in predicting streamflow response to forest removal and planting, respectively, is possibly applicable in the coastal systems also. Furthermore, microtopography influencing both surface and subsurface storage (Amoah, Amatya, \& Nnaji, 2013; Hu, Bao, Shi, Wang, \& Lu, 2020; Walega, Amatya, Caldwell, Marion, \& Panda, 2020; Wu \& A. Johnston, 2008), role of dis(connectivity) (Ares, Varni, \& Chagas, 2020) and drainage network pathways (Amatya et al., 2019; Todd, Buttle, \& Taylor, 2006) have been shown to be important factors affecting runoff and its timing. Thus, a careful examination of such spatial catchment characteristics, including the above and below canopy vegetation leaf area that regulate soil moisture and ET influencing the runoff from the watersheds is fundamental for an accurate interpretation of the water yield, as part of the LLP restoration evaluation study (Trettin et al., 2019).

Paired watershed approach, where two neighboring watersheds (one reference or control and one treatment) are monitored concurrently during calibration (pre-treatment) and post-treatment periods (Jayakaran et al., 2014; Loftis, MacDonald, Streett, Iyer, \& Bunte, 2001; Ssegane et al., 2013), has been extensively used to assess effects of water management and silvicultural practices on hydrologic variables (runoff, peak flow rate, ET, and water table), water yield, and ecosystem services (Amatya, Gregory, \& Skaggs, 2000; Bosch \& Hewlett, 1982; Brown, Zhang, McMahon, Western, \& Vertessy, 2005; Tomer \& Schilling, 2009). The control watershed accounts for year-to-year or seasonal climate variations and management practices remain the same during the pre-treatment calibration period (Clausen \& Spooner, 1993). The basis of the paired watershed approach is that there is a significant, quantifiable relationship between the two watersheds that provides a basis for comparing whether a treatment alters that relationship. This approach is used primarily on $1^{\text {st }}$ order watersheds (Bosch \& Hewlett, 1982; Bren \& Lane, 2014) although its applicability for predicting effects on flood events on larger systems has been challenged (Alila, Kuraś, Schnorbus, \& Hudson, 2009;).

The key objective of this study is to affirm baseline hydrology, of a paired watershed reported earlier (Binstock, 1987; Richter, 1980), for the current pre-treatment period for testing later the hypothesis that the watershed-scale restoration of LLP will increase water yield, primarily due to reduced evapotranspiration (ET). This may likely be result of managing LLP with frequent prescribed fire for open canopy conditions with low overstory stocking, sparse understory vegetation and therefore less LAI.

\section{Baseline Paired Hydrology Relationship}

The approach for this study is to utilize the $1^{\text {st }}$ order paired watersheds (WS77 - treatment and WS80 reference) on the Santee Experimental Forest (SEF), which is located within the FMNF (Figure 1; Table A.1).

\section{Figure 1}

This study has a long-term record to support the comparative analyses including a statistically significant relationship between monthly flows established between control and treatment watersheds (Binstock, 1987) to evaluate effects of partial prescribed burning on streamflow for 1976-1980 (Table 1) (Richter, 1980; Richter, Ralston, \& Harms, 1982). Monitoring of the paired watersheds discontinued in early 1982 was revitalized 
again in 1990 soon after Hurricane Hugo (1989) significantly damaged forest in the region (Hook, Buford, \& Williams, 1991). Richter (1980) found, on an average annual basis, streamflow from WS77 and WS80 were $28 \%$ and $20 \%$ of precipitation. Richter also analyzed four possible explanations for varying unit area water yield from the paired watersheds as a) differences in deep seepage losses, b) difference in vegetation which influences ET and interception, c) watershed boundaries, and d) calibration errors in weir rating tables. Richter (1980) suggested negligible deep seepage losses for these poorly drained soils and found no evidence of weir leakage on both watersheds. Based upon seasonal flows and vegetation composition analysis, the author also argued that differences in water yield cannot be explained by a hypothesis of vegetational differences. His analysis also ruled out the possible watershed boundary effects in these low-gradients systems. However, Richter (1980) suggested that because of the consistency in annual ET (rainfall - runoff) and predictability of WS77 runoff measured more accurately, differences were attributed to WS80 runoff estimates, particularly for high flows. Nonetheless, the authors also suggested a need for calibration of both stream gauges. In a paired watershed study on grasslands in Uruguay, Chescheir, Skaggs, \& Amatya (2009) also found similar inherent differences between the paired watershed for the pre-treatment period with higher runoff from treatment than the control, which was attributed to higher baseflow from the treatment watershed likely due to its lower ET from its shallow soils or groundwater inflow from outside of the watershed.

\section{Table 1}

Interestingly, the paired pre-Hugo flow relationship (WS77 > WS80) reported by Richter (1980) reversed three years after Hugo for 10 years (WS80 > WS77) before the relationship reportedly recovered to baseline levels by 2004 as did the forest stands (Jayakaran et al., 2014). Jayakaran et al. (2014), who analyzed data through 2011 (Table 1), suggested that lowered vegetative water use likely increased outflows on both due to loss of trees following hurricane impact. However, WS77 was able to recover to pre-hurricane runoff by 1993 (four years post-Hugo) due to the greater abundance of pine seedlings and saplings in that watershed in contrast with the control (WS80) which recovered its flow pattern by 2003 only. Jayakaran et al. (2014) noted that it seems likely that high rainfall in 2003 would have created saturated soils on both watersheds during that year, with substantial water table draw down during the following year's (2004) drought conditions, somewhat confounding the exact timing and mechanisms responsible for the onset of flow relationships to pre-Hugo period. Therefore, the authors cautioned that whether the wet and dry years accelerated the recovery state similar to historical flow conditions by 2004 is an area for further study.

Thus, it is important to properly evaluate and establish the paired flow pattern and calibration relationship of watersheds disturbed by natural or anthropogenic disturbances using a stable pre-treatment period of sufficient record length such that it is consistent with pre-disturbance baseline levels and also is significant and quantifiable before applying it for another treatment. For example, a review of hydrologic recovery on three forested watersheds in Northeastern US (Hornbeck et al., 1993) demonstrated that it took 7 to 25 years for the annual water yields to return to pre-harvesting volumes. The difference in hydrologic recovery rate was attributed to difference in the percent composition of tree species that re-grew after 100\% clear-cutting (e.g., conversion of pre-treatment hardwood to post-treatment coniferous). In a long-term study on a managed pine forest site in coastal North Carolina (NC) (Amatya \& Skaggs, 2011), where the treatment watersheds underwent water management (1990-1995), harvesting/planting (1995-1997), and thinning (2002) treatments with 1988-1990 as the calibration period, only daily water table was reportedly similar to calibration period for the forest recovered within 10 years by 2004 (Amatya, Miwa, Harrison, \& Trettin, 2006). Later, Ssegane et al. (2013) used 2007-2008 as the $2^{\text {nd }}$ calibration period and found no significant $(\alpha=0.05)$ difference in daily water table elevation relationships but different daily flow relationships between the two calibration periods at the same NC site. With both the calibration periods spanning just two years, the authors attributed the observed differences in the flow relationships between these periods to modification of soil properties during the operational silvicultural activities during clear-cutting and logging. In another study at the same NC site, Ssegane et al. (2017) found statistically significant pre-treatment relationships, consistent with those from the 1988-1990 pre-disturbance level, using only 762 days and 608 days (for two treatment watersheds) of stable calibration period from 2009 to 2012 period that included some disturbances in the watersheds. Bren and Lane (2014) found a rapid increase in quality of calibration relationship as the record length increases 
but with no increase after 3-year length for all temporal scales of flow. The authors suggested a 5-year period was adequate, consistent with Clausen and Spooner (1993) for most purposes and main advantage of longer period they reported was the lower mean errors.

Thus, based on above studies, particularly Jayakaran et al. (2014), we assumed that the paired watersheds WS77 and WS80 have fully recovered by 2019 after 30 years since Hugo disturbance (1989) and the 9-year period (2011-2019) (Table 1) data should be adequate for evaluating the paired flow (runoff) relationships between the watersheds using three main objectives below.

Objective 1: Evaluate annual and seasonal rainfall-runoff relationships using runoff coefficients (ROC) between the paired watersheds compared to two earlier monitoring periods (1969-1978 (pre-Hugo) and 20042011 (post-Hugo)) (Table 1);

Hypothesis 1: The pre-treatment ROC between the watersheds will be same for annual periods as well as for each of the dormant and growing seasons with higher ROC for the dormant than for the growing season on both watersheds. The paired ROCs will also be not different from the pre- and post-Hugo periods.

Objective 2: Evaluate difference in monthly runoff response between the paired watersheds compared to two previous periods (Table 1 );

Hypothesis 2: The difference in monthly runoff response between the paired watersheds will not be different from the pre- and post-Hugo periods.

Objective 3: Evaluate the monthly runoff calibration relationship with and without a month (October 2015) yielding an extreme runoff, as an outlier, compared to two previous periods (Table 1);

Hypothesis 3: The paired monthly runoff calibration relationship with the outlier will be different but not different without an outlier from the relationships for two early periods. The relationship without an outlier is significant and quantifiable with predictive capability.

In addition, we also expanded a discussion on possible explanations for inherent difference in runoff between the paired watersheds building upon earlier studies (Jayakaran et al., 2014; Richter, 1980).

\section{MATERIALS AND METHODS}

\section{Site Description}

The paired watersheds (WS77 and WS80) drain into Fox Gulley Creek and further down to Turkey Creek, a tributary of Huger Creek. These are parts of the headwaters of Huger Creek, a $4^{\text {th }}$ order stream, which is a major tributary of East Branch of Cooper River that drains into Charleston Harbor (Fig. 1a). Basic characteristics of the watersheds are given in Table 1. The vegetation on WS77 is dominated by loblolly pine (Fig. 1b), planted for silvicultural research in the late 1970's. The vegetation on WS80 is a mixed hardwoodpine stands regenerated since Hugo. Soils on the watersheds are poorly to moderately-well drained sandy clay loam overlaying clay typified by Wahee and Craven soil series in the uplands and Megget and Betheera soils in the riparian zones (Fig. 1b). The climate is warm-humid temperate, with average daily temperature of $17.8^{\circ} \mathrm{C}$ and annual rainfall of about $1370 \mathrm{~mm}$. Chronological activities on both the watersheds are given in Table A.1 and more details are described elsewhere (Amoah et al., 2013; Dai, Trettin, \& Amatya, 2013; Harder et al., 2007).

\section{Hydro-meteorologic Monitoring:}

Beginning in 2003 digital records of precipitation were collected using automatic tipping bucket gauges backed up by a manual gauge at Met5 station on WS77 and at Met25 station on WS80, respectively. Data from nearby gauges were also used for gap-filling (Figs. 1a, 1b). Digital measurements of stage, also beginning in 2003, were recorded every 10-minutes by the Teledyne ISCO flowmeters installed upstream of both the WS77 and WS80 watershed weir outlet gauging stations (Fig. 1a, 1b). These digital stage data were used with established rating curves for compound V-notch weirs for estimating streamflow rates (Amatya \& Trettin, 2019a, 2019b). Daily average weather parameters obtained from weather sensors installed above the forest 
canopy on a 27-m tall tower on WS80 in 2010 (Fig. 1a, 1b) were used to estimate daily Penman-Monteith (P-M) (Monteith, 1965) based PET for the forest conditions following Amatya and Harrison (2016) (Table 2). A 3-m weather station installed on an open grass area at the nearby SEF Headquarters (SHQ) (Fig. 1a) provided data for gap-filling.

\section{Table 2}

Water table (WT) in well $\mathrm{H}$ and well $\mathrm{D}$, both of approximately 2.8 to $3 \mathrm{~m}$ deep, in upland and riparian setting, respectively, of WS80 and well J on uplands within WS77 have been measured on an hourly basis since 2004 using pressure transducers with a datalogger (Figs. 1a and 1b). Well K near the riparian area on the WS77 was installed in 2018 (Fig. 1b). Plots of daily water table depths on Well J (WS77) and Well H (WS80) for 2011-2019 is presented in Figure A.

Biweekly measurements of leaf area index (LAI) were conducted in 2019-2020 ( $\mathrm{n}=9$ ) at three locations proposed for LLP treatment on WS77 (Fig. 1b). We used average LAI measured during 2008-2009 ( $\mathrm{n}=40$ ) and reported by Dai et al. (2013) for WS80 watershed, assuming it remained unchanged in these undisturbed forest stands. Details of the LAI measurements and comparative analysis with the WS80 LAI are given in Appendix A.1 and Figure A.2.

Details of all hydro-meteorologic measurements including data quality control can be found elsewhere (Amatya \& Trettin, 2007, 2019a; Amoah et al., 2013; Dai et al., 2013; Harder et al., 2007) and data access links are presented in Table A.2.

\section{Data and Statistical Analyses}

Measured daily rainfall, streamflow or runoff (watershed area-based depth), and PET estimated from the daily weather data for the 2011-2019 period, were used to obtain monthly and annual totals. Monthly rainfall and runoff were further summed to obtain the dormant season (November - April) and growing season (May - October) totals, and total annual runoff. Daily flow data were used to derive daily flow duration curves to identify differences in flow magnitudes, frequencies, and duration of daily runoff between the watersheds. Daily WT depths were obtained by integrating hourly data.

Annual and seasonal runoff coefficients (ROC, runoff/rainfall) values for both the dormant and growing seasons were computed for both watersheds to test the Hypothesis 1. Measured monthly runoff data were used to a) compare mean monthly difference in flow between the paired watersheds against two earlier periods to test Hypothesis $\mathbf{2}$ and b) develop a calibration regression of monthly flow between the paired watersheds to test Hypothesis $\mathbf{3}$. An analysis was conducted to identify outliers in the monthly runoff by using the 1.5 times the interquartile range (IQR) from the mean shown in a Box Plot, in which the values outside this range are excluded in the regression development.

The Shapiro-Wilk normality test (SAS, 2006) showed a non-normal distribution $(\mathrm{p}<0.001)$ of monthly runoff. We, therefore, used nonparametric Wilcoxon signed-rank test to assess significance of differences in mean monthly runoff between the two watersheds measured for 108 months or nine (2011-2019) years. Ordinary least squares regression (OLS) was used to develop a calibration equation between the control and treatment watersheds and its significance test (Warton, Wright, Falster, \& Westoby, 2006). However, since DurbinWatson test (SAS, 2006) showed a positive autocorrelation of the monthly runoff on both the watersheds, we compared for differences between regression relationships using OLS versus using a resampling technique that accounts for serial correlation in time series and geometric mean (GM) regression, following (Ssegane et al., 2017), using the $t s$ andlmodle2 R-statistical package (R Development Core Team, 2015). In this approach, the original data were resampled in pre-determined blocks 1000 times to estimate regression coefficients. GM, also known as the reduced major axis regression, is suited for paired watershed analysis because it assumes errors are associated with both dependent (treatment watershed) and independent (control watershed) variables (Friedman, Bohonak, \& Levine, 2013). However, the regression coefficients for the OLS and GM were not statistically different and thus, proceeding analysis focused on OLS. The coefficient of determination $\left(R^{2}\right)$, Nash-Sutcliffe efficiency (NSE), and the root mean squared error (RMSE) were used to evaluate the strength 
and significance of the OLS regression. For $R^{2}\left(0\right.$ [?] $R^{2}$ [?] 1.0), and NSE (-[?] [?] NSE [?] 1.0), a value of 1.0 is indicative of an optimal model. All statistical significance tests for similarity with no difference were conducted for $\alpha=0.05$ level.

We also calculated change in soil-water storage $(\Delta S)$ using an approximate water table fluctuation method (WT- $\Delta$ S) (Amatya et al., 1996; Callahan, Vulava, Passarello, \& Garrett, 2012) that used average drainable porosity $\left(\lambda_{\mathrm{d}}\right)$ of 0.05 for the soil profile, as an average from three different methods (e.g. average from soil moisture retention data, ratio of rainfall to water table rise, and an estimate using DRAINMOD (Skaggs, 1978) for dominant Wahee soil (Harder et al., 2007) for both the watersheds, in conjunction with the monthly water table depths measured on Well J for WS77 and Well H on WS80) for the 2011-2019 period. The plot of calculated monthly $\Delta \mathrm{S}$ is presented in Figure A.3. This is only a simple approximation that considers for storage change due to WT drop by ET and drainage, and may not work well for storage change due to recharge and rainfall (Acharya et al., 2012).

We also used morphometric analysis, among other factors, for explaining inherent differences in streamflow between the paired watersheds, with higher flow from the treatment than the control watershed since the historic study (Richter, 1980). Morphologic analysis was conducted by deriving the hypsometric curves and indices (Langbein, 1947; Strahler, 1952) to examine the effects of land morphologic characteristics on runoff generation for the paired watersheds. A system for automated geoscientific analysis (SAGA)-GIS (Olaya \& Conrad, 2009) and LiDAR based DEM were used to generate the hypsometric curves of WS77 and WS80. The hypsometric integral ( $H I$ ), skewness (skew), and kurtosis of the hypsometric curves were computed using general formulations by Harlin (1978) and Perez-Pena, Azanon, and Azor (2009).

\section{RESULTS}

\section{Annual Rainfall, Streamflow (Runoff), and Runoff Coefficient (ROC)}

The recorded minimum (WS77- $977 \mathrm{~mm}$; WS80 - $934 \mathrm{~mm}$ ) and maximum (WS77 - $2146 \mathrm{~mm}$; WS80 - 2171 $\mathrm{mm}$ ) annual rainfall on both watersheds occurred in the same years, 2011 and 2015, respectively, with a mean annual of $1476 \mathrm{~mm}$ (WS77) and $1496 \mathrm{~mm}$ (WS80) (Table 2). The mean annual runoff of $399 \mathrm{~mm}$ on the WS77 was almost 30\% higher than that on the WS80 (309 mm). Accordingly, the calculated rainfall normalized annual ROC values were almost consistently higher, with the mean of 0.24 on the WS77 than the mean of 0.19 on WS80 but not significant $(\mathrm{p}=.17)$. These mean ROC values were not statistically different $(\mathrm{p}>0.80)$ from those reported for the pre-Hugo period $(1969-1978)(\mathrm{WS} 77 \mathrm{ROC}=0.25$; WS80 ROC $=$ 0.18) (Amatya et al., 2006; Richter, 1980) as well as the 2004-2011 period (WS77 ROC $=0.18$; WS80 ROC $=0.14 ; \mathrm{p}>0.20)$. The annual response of runoff to rainfall for the 2011-2019 period was also not different between the watersheds, with Flow $=0.79$ Rain $-787 ; \mathrm{R}^{2}=0.97 ; \mathrm{p}<0.001$ for WS77 and Flow $=0.80$ Rain - 882; $\mathrm{R}^{2}=0.93 ; \mathrm{p}<0.001$ for WS88, supporting Hypothesis 1 .

Seasonal ROC was also consistently higher on the WS77 than on the WS80, but no statistical difference between the means of 0.28 for WS77 and 0.24 for WS80 with p $=0.58$ in dormant season and means of 0.21 for WS77 and 0.15 for WS80 with $\mathrm{p}=0.30$ for the growing season. These ROC values were found to be similar in differences (WS77 > WS80) compared to the 1970-1978 historic data between the watersheds for each season, with the ROC of 0.49 and 0.40 for the WS77 and WS80 for the winter dormant season and 0.24 (WS77) and 0.18 (WS80) for the summer growing seasons (Richter, 1980), again supporting Hypothesis 1. However, the current dormant season ROC values were much lower than for the historic period.

Annual ET, calculated as a difference of annual rainfall and runoff assuming no change in storage, varied from $903 \mathrm{~mm}$ in relatively dry year of 2011 to as high as $1272 \mathrm{~mm}$, with an average of $1168 \mathrm{~mm}$ on the control watershed (WS80) (Table 2). The annual ET was consistently lower on the WS77 than the WS80, but not different $(\mathrm{p}=0.07)$, with a mean of only $1097 \mathrm{~mm}$, primarily due to its higher runoff than that of the WS80. The mean annual ET on the WS80 was very close to estimated P-M PET, with no difference (p $=0.46)$, while the ET on WS77 was significantly lower $(\mathrm{p}=0.046)$ than the PET, potentially indicating soil water limitations (Table 2). However, annual ET increased insignificantly with rainfall yielding higher $\mathrm{R}^{2}$ (0.71) on WS77 than on WS80 $\left(\mathrm{R}^{2}=0.42\right)$, indicating again WS77 as more soil water limited than WS80. 


\section{Monthly Runoff between the Watersheds}

The mean monthly runoff for 2011-2019 presented in Figure 2 was not statistically different $(\mathrm{p}=0.41)$ between WS77 and WS80, with WS77 averaging $33.3 \mathrm{~mm}(0-597 \mathrm{~mm})$ and WS80 averaging $25.7 \mathrm{~mm}(0-599$ $\mathrm{mm})$. Similarly, there was no difference in variance between the WS77 and WS80 (p = 0.37). A large monthly flow of $598 \mathrm{~mm}$ due to an extreme rainfall event of October 3-4, 2015 (Amatya, Harrison, \& Trettin, 2016) was assumed to be an outlier.

\section{Figure 2}

Data in Figure 3 for monthly difference in runoff between the watersheds (WS80 - WS77) for 2011-2019 period showed WS77 almost consistently yielding somewhat higher, but not statistically different (see below), flows (negative difference) than the WS80, except for few periods, consistent with pre-Hugo (1969-1978) pattern (Richter, 1980). The mean monthly runoff difference of $-7.54 \mathrm{~mm}( \pm 1.68 \mathrm{~mm})$ between the WS80 and WS77 for the 2011-2019 period (Figure 3) is almost double of $-3.89 \mathrm{~mm}( \pm 1.09 \mathrm{~mm}$ ) obtained by (Jayakaran et al., 2014) for the 2004-2011 period when the recovery of forest stands occurred, and slightly lower than the pre-Hugo (1969-1978) mean of -8.57 mm $( \pm 1.65) \mathrm{mm}$. However, the runoff difference for the 2011-2019 period was not statistically different $(\mathrm{p}=0.34)$ from only the $1969-1978$ period but barely different $(\mathrm{p}=0.049)$ from the 2004-2011 period although difference in both periods was in the same direction. Thus, this result accepts the Hypothesis 2, supporting validity of the 2011-2019 period data for pre-treatment calibration.

\section{Figure 3}

\section{Ordinary Least square regression versus geometric mean regression for paired monthly runoff}

Plot in Figure 4 shows the comparison of relationships of monthly runoff using the ordinary least square (OLS) and geometric mean regression (GMR) between the control watershed (WS80) and the treatment watershed (WS77). However, the regression coefficients for the OLS (WS77 $=0.99 *$ WS80 $+7.60 ; \mathrm{R}^{2}=0.93$ ) and GMR $\left(\right.$ WS77 $=1.03(0.98-1.08) *$ WS $\left.80+6.68(5.28-8.00) ; \mathrm{R}^{2}=0.93\right)$ were not statistically different $(\alpha$ $=0.05$ ). The OLS relationship falls within the GMR $95 \%$ confidence limits (shown in parentheses for both the slope and intercept). Therefore, subsequent analysis focused only on OLS regression.

\section{Figure 4}

\section{Calibration Regression of Paired Monthly Flows}

Plots in Figures 5a and 5b show the regression relationships of measured monthly runoff between the control (WS80) and treatment (WS77) watersheds for the pre-treatment calibration period of 2011-2019 with (a) all data and (b) with exclusion of October 2015 month with 2-day rainfall of near $500 \mathrm{~mm}$ producing an extreme runoff event on $3^{\text {rd }}$ October. Thus, October 2015 flow was considered an outlier because it is more than five standard deviations away from the mean monthly flow.

\section{Figure 5}

The regression including the extreme October 2015 runoff (Fig. 5a) yielded a significant monthly runoff relationship (WS77 $=0.99 * \mathrm{WS} 80+7.60 ; \mathrm{R}^{2}=0.93 ; \mathrm{NSE}=0.93, \mathrm{RMSE}=17.4 \mathrm{~mm}$ ) between the paired watersheds obtained in which the both the slope, close to unity and an intercept of $7.6 \mathrm{~mm}$, were significant $(\mathrm{p}<0.001)$. However, this relationship may have been biased by this one single extreme runoff. With this observation excluded, the new relationship (WS77 $=1.03^{*} \mathrm{WS} 80+7.00 ; \mathrm{R}^{2}=0.82 ; \mathrm{NSE}=0.79$, RMSE $=18.5 \mathrm{~mm}$ ) was still significant $(\mathrm{p}<0.001)$, comparable to 2004-2011 relationship (Jayakaran et al., 2014) shown in Figure 5b, supporting part of Hypothesis 3. The significant intercept value represents as an average difference in monthly flow, with WS77 insignificantly higher than WS80 discussed above (Fig. 3) and below using daily flow frequency duration data. The variability of flow around the $95 \%$ confidence limits of regression line shows somewhat higher discharges on WS77 compared to WS80 for most of the months with flow less than $100 \mathrm{~mm}$. However, the above regression with slope (1.03) and intercept (7.0) for the 2011-2019 pre-treatment period was significantly different from the 1969-1978 period with slope $=1.32$ and intercept of 1.3 (Fig. 6), (which was similar to 1.36 slope and zero intercept obtained by (Richter, 1980), 
but not different from the recent 2004-2011 post-Hugo period with 1.08 slope and 2.65 intercept (Jayakaran et al., 2014), rejecting and accepting parts of the Hypothesis 3.

The IQR outlier analysis eventually included monthly runoff only up to $110 \mathrm{~mm}$ on both watersheds for the regression, excluding months of October 2015 and 2016 on both watersheds, and also September 2019 for WS77 which exceeded that threshold. The new 2011-2019 regression relationship with its $95 \%$ confidence boundaries obtained after omitting the 1.5 times IQR based outliers yielded a significant regression of WS77 $=1.24 *$ WS $80+4.3 ; \mathrm{R}^{2}=0.76$ and is shown in Figure 6 . In this case both the pre- (1969-1978) and post-Hugo (2004-2011) regression lines fell well within the $95 \%$ boundaries. The wide variability of observed runoff around the regression line between the watersheds is also visible.

\section{Figure 6}

\section{Daily Flow (Runoff) Duration Curves}

Daily flow frequency duration curves were compared between the watersheds in Figure 6. Daily runoff were consistently lower from WS80 compared with WS77 supporting the 1969-1978 historic period pattern (Richter, 1980). The magnitude of daily runoff of $20 \mathrm{~mm}$ exceeded less than nearly $1 \%$ of time on WS77 compared to less than only $0.6 \%$ of time (Figure 6 ). For $10 \%$ of the time daily runoff exceeded $1.57 \mathrm{~mm}$ on WS77 versus $1.26 \mathrm{~mm}$ on WS80. Similarly, WS80 had zero runoff $43.1 \%$ of the time compared to $39.8 \%$ of time on WS77 in contrast with $43.8 \%$ and $35.6 \%$ of the time on WS80 and WS77, respectively for the 19691978 period. This zero-runoff pattern for historic and current period was found similar for the control (WS80) but not for the treatment where more dry days were observed for the recent period. Also, the difference in percent time of zero runoff days between the watersheds was found smaller $(3.3 \%)$ for the current period compared to $8.2 \%$ for the 1969-1978 period although the two periods covered different number of days. Runoff exceeded $115 \mathrm{~mm} \mathrm{day}^{-1}$, as extreme events, for less than only $0.1 \%$ of time with a steeper slope on both, which is an indicative of flooding regime on these poorly drained watersheds consistent with (Amatya et al., 2019).

\section{Figure 7}

\section{DISCUSSION}

The paired watersheds, besides being adjacent, are similar in many characteristics including the area, topography, drainage, dominant soil types (Table 1), and the mean Leaf Area Index (LAI) of the existing forest stands (A.1 and Fig. A.2). Despite of these similarities, treatment watershed (WS77) yielded almost consistently higher (but not significant) monthly runoff than WS80 (Table 2), except for few periods with saturated soils (WT near the surface) in July 2013, March and November-December 2015, and October 2016 (Fig. A.1), when WS80 runoff exceeded that on WS77 (Fig. 4). These events resulted in large peak discharges on WS80, consistent with (Harder et al., 2007) who found exponentially increasing runoff as the Well H WT neared the surface or ponded (Fig. A.3). The insignificant higher monthly runoff (WS77 > WS80) (Fig. 4), consistent with earlier studies (Jayakaran et al., 2014; Richter, 1980) is also supported by daily flow duration curves for the 2011-2019 (Fig. 7). Richter (1980) in his study prior to Hugo (1989) ruled out the possibility for this difference in flow, due to groundwater seepage, drainage area, and vegetation effects. The author, however, speculated some possible shortfalls in WS80 flow measurements, particularly during high flow periods with daily flow $>5 \mathrm{~mm}$ (Fig. 7). Since that study several recent studies have verified the flow measurements on WS80 (Amatya et al., 2006; Harder et al., 2007; Jayakaran et al., 2014), the authors believe the measurements are consistent, except for tropical storm events of 2015 and 2016 (Amatya \& Trettin, 2019a) when the flow rates were estimated using theoretical equations. Below we examine few other potential factors that may possibly help explain the reasons for WS77 yielding higher, but not significant, runoff than the WS80.

Climate is a primary driver of the runoff on both watersheds. The mean annual rainfall between the WS77 and WS80 watersheds was not significantly different $(\mathrm{p}=0.90)$, but both are higher than the long-term average of $1370 \mathrm{~mm}$ reported by (Dai et al., 2013) for 1946-2008 period, indicating the study period as 
relatively wet on average. However, seasonal and annual rainfall, were shown to be not significantly $(\alpha=$ 0.05) different between the two watersheds although the WS77 experienced somewhat higher rainfall than the WS80 (Table 2). This was consistent with (Jayakaran et al., 2014) who suggested that given the similarity of rainfall across the two watersheds, relative changes in streamflow are a good indicator of relative changes in ET dynamics between the two watersheds. However, the watersheds are different in three important land use and management aspects which are discussed below.

First, there is a historic land use difference between WS80 and WS77. The lower reaches of WS80 were used for rice cultivation. As a result, there are historical water management structures within the watershed which WS77 does not have. This was consistent with findings from LiDAR data analysis which also revealed some depressions caused by legacy dikes on downstream riparian areas of WS80 (Amatya, Trettin, Panda, \& Ssegane, 2013). Using $0.3 \mathrm{~m}$ resolution topographical maps, (Amoah et al., 2013) found nine times higher overall surface depressional storage capacity (DSC) on WS80 than the WS77 (Table 1) further supporting the higher depressional values on WS80. In addition, National Wetland Inventory data showed larger (30\%) wetland areas compared to $11 \%$ on the WS77 (Table 1). Thus, it is very likely that the high WS 80 DSC values may potentially contribute to higher seasonal water table, increased ET, and reduced streamflow due to its modulated peaks caused by the storage as evidenced by flatter slope of WS80 than that of WS77 in the range of approximately $10-110 \mathrm{~mm}$ daily flow (Fig. 7). This is further evidenced by daily flow and 10-minute hydrographs for two events of June 12 and September 05 in 2019, as an example (Figs. 8a and 8b), in which the flow rates on WS77 with much lower DSC were 3-4 times higher than on the WS80 consistent with other years also (not shown). These observations are consistent with other studies (Acreman \& Holden, 2013; Amatya, Chescheir, \& Skaggs, 1995; Hu et al., 2020; Rains et al., 2016; Vogel \& Fennessey, 1995; Walega et al., 2020) who reported water table position and microtopography influencing storage, are critical factors that affect streamflow patterns, stormflow peaks, and volume on shallow coastal forests. For example, Rains et al. (2016) noted that the cumulative effect of depressions (WS80 in our study) can play an important role in landscape-scale hydrology by regulating the frequency, magnitude, timing, duration, and rate of flows to downgradient waters along overland and groundwater flow path. Similarly, Acreman and Holden (2013)'s conclusions, on five characteristics (landscape location and configuration, topography (larger areas of wetlands), soil characteristics, soil moisture status (generally larger storage on WS80 with higher ET), and drainage management (higher drainage density on WS77 shown in Table 1) largely determine influence on floods, are consistent with our observations on these two watersheds discussed above.

\section{Figure 8}

Secondly, a contemporary difference between the two watersheds is that WS80 has not received any forest management activities since it was established in 1968, in contrast to WS77 which has been used for loblolly pine silvicultural research and has been actively managed with prescribed fire (in 2-3 years cycle) for the past 20 years (Fig. 3), with a potential to increase flow soon after the fire (Ebel, Moody, \& Martin, 2012; Robichaud, 2000). For example, reduced understory vegetation, for that matter the LAI and ET, due to the operational burning prescribed in March 2013, April 2016, and April 2018 (Fig. 3) might have contributed to some temporary increased runoff in subsequent months of June 2013, August 2016, and August 2018, respectively.

The fact that the mean monthly difference (WS77-WS80) in runoff $(-7.54 \mathrm{~mm})$ for the 2011-2019 period was found not different from the 1969-1978 period $(-8.56 \mathrm{~mm})$ but barely different from the 2004-2011 period $(-3.89 \mathrm{~mm})$ further indicated the complete recovery of regenerated forests reportedly recovered by 2004 (Jayakaran et al., 2014).

Third, the active management of WS77 results in a stand that is predominately loblolly pine, in contrast to WS80 which is mixed hardwood pine forest. Despite this difference in forest stand composition, the mean LAI of $2.31 \mathrm{~m}^{2} \mathrm{~m}^{-2}\left(1.23 \mathrm{~m}^{2} \mathrm{~m}^{-2}-3.36 \mathrm{~m}^{2} \mathrm{~m}^{-2}\right)$ measured on control watershed with pine-mixed-hardwood forest (Dai et al., 2013) was not statistically significant $(\mathrm{p}=0.34)$ from the mean of $2.54 \mathrm{~m}^{2} \mathrm{~m}^{-2}\left(1.62 \mathrm{~m}^{2}\right.$ $\mathrm{m}^{-2}-2.92 \mathrm{~m}^{2} \mathrm{~m}^{-2}$ ) measured in 2019-2020 on the WS77 with pine stands (Fig. A.2). Although the WS77 mean LAI was slightly higher than on the WS80, the growing season LAI, with a potential to influence ET, 
was higher (as high as 4-6 $\mathrm{m}^{2} \mathrm{~m}^{-2}$ ) in some plots during growing season on the WS80. So, the lower WS80 runoff during growing season was also partially attributed to higher ET of the mixed hardwood-pine forest. For example, in 2019 (Fig. 8) despite lower WS77 rainfall $(235 \mathrm{~mm}$ ) due to Hurricane Dorian (September 5) than WS80's $242 \mathrm{~mm}$ (Fig. 8a), the WS77 flow was larger by $80 \mathrm{~mm}$ than WS80. This was likely due to shallower WT with a reduced storage on WS77 than on the WS80 (Fig. A.3) in late August/early September (Figs. 8c and 8d) with early initiation of flows. Accordingly, WS80, with deeper WT and larger storage possibly caused larger ET loss than WS77, had no flows for 54 days until this event in contrast with only 2 days on WS77. This pattern, with deeper WT depths with larger growing season deficits on WS80 than on the WS77, was also evident during of 2011 to 2014 summer periods, as well as briefly in 2016, 2017 and 2019 when WT fell below $100 \mathrm{~cm}$ (Figs A.1 and A.3), potentially contributing to higher ET and lower flows.

In addition, land morphology defined by hypsometric curve also might have played a role in runoff difference between the watersheds. The shape of the hypsometric curve is represented by a hypsometric integral, HI (Luo, 2000; Vivoni, Di Benedetto, Grimaldi, \& Eltahir, 2008), with a value of 0.5 representing a threshold between concave (HI < 0.5) and convex (HI [?] 0.5) hypsometric forms. Vivoni et al. (2008) found, keeping all other watershed variables constant (e.g., land use and land cover, and rainfall), modeled watersheds with a higher HI yielded higher runoff than the one with the lower HI. Concave hypsometric curves for WS77 and WS80 with their statistics presented in Figures 9a and 9b clearly indicate that WS77 may be expected to yield more runoff than WS80 because of its higher HI of 0.405 compared to 0.285 for WS 80 until 2001 and 0.313 thereafter (due to drainage area change from 206 ha to 160 ha; Table A.1), which was still $<0.405$ (WS77). This suggests that shape of the basin hypsometry could also be another reason for the difference in runoff between the two watersheds.

\section{Figure 9}

The pre-treatment monthly paired flow relationship without an outlier for the October 2015 extreme runoff (Fig. 7a) was not significantly different from the earlier 2004-2011 relationship (Fig. 5b) reported by (Jayakaran et al., 2014). The estimated outlier runoff of $599 \mathrm{~mm}$ was dominated by one-day (October 03) estimated extreme runoff of $311 \mathrm{~mm}$ on WS80. The peak flow rate for this event, estimated at $17.4 \mathrm{~m}^{3} \mathrm{~s}^{-1}(10.9$ $\mathrm{m}^{3} \mathrm{~s}^{-1} \mathrm{~km}^{-2}$ ) was assumed to have exceeded 500-yr flood discharge (Amatya et al., 2016; Amatya \& RadeckiPawlik, 2007). Interestingly, when IQR criterion was further used to omit extreme runoff as outliers, two months exceeding $100 \mathrm{~mm}$ runoff on both watersheds in October 2015 (indirect effect of Hurricane Hoaquin with $500 \mathrm{~mm}$ rain in 2-days), in October 2016 (Hurricane Mathews with a 2-day rainfall of $295 \mathrm{~mm}$ ), and in September 2019 (only on WS77) (Hurricane Dorian with a 2-day rainfall of nearly $200 \mathrm{~mm}$ ), the slope of new regression increased from 1.03 to 1.24 (Figs. 5b and 6). Accordingly, the $95 \%$ confidence bounds for the new slope encompassed both the regression lines for 1969-1978 (slope of 1.32) and 2004-2011 (slope of 1.19) periods, indicating no difference in three relationships. This may explain that the current relationship is being influenced by climatic extremes in contrast with the two previous periods. However, the fact that only the 2004-2011 regression, but not the 1969-1978, was similar to the 2011-2019 without an outlier indicates influence of similar climate on runoff during the two recent periods, but different from the historic 19691978. This is supported by the observations of Dai et al (2013) who reported increased number of annual average storms $>50 \mathrm{~mm}$ in the 1982 to 2008 period compared to 1946-2008, with even more increasing trends by 2017 (not shown). This is also consistent with Kelly et al. (2016) who reported that interactive effects of changes in observed precipitation trends and forest management (operational prescribed burning on WS77), significantly alter expected streamflow most often during extreme events. We, therefore, suggest, that although the relationship obtained using the 1.5 IQR criterion was found similar to those for both the 2004-2011 and 1969-1978 periods, the relationship obtained by omitting runoff from just the October 2015 extreme event, that was not different from the 2004-2011 period, is more justified for its application in treatment effects evaluation on WS77 water yield.

Our computed p-value, $\mathrm{R}^{2}$, NSE, and RMSE statistics characterizing statistical significance and predictive quantifiable regression are also consistent with similar statistics $\left(\mathrm{R}^{2}=0.97, \mathrm{NSE}=0.97\right)$ for paired daily flow relationships for 1988-1989 and higher than $\mathrm{R}^{2}=0.48$, NSE $=0.34$ for 2007-2008 calibration period 
reported by Ssegane et al. (2013) in their NC pine forest study. Those values were also similar to $\mathrm{R}^{2}=0.83$, $\mathrm{NSE}=0.82$ and $\mathrm{R}^{2}=0.91$, NSE $=0.91$ for two separate paired watersheds for the 2009-2012 calibration periods reported for the studies in coastal North Carolina by (Ssegane et al., 2017).

Thus, the strong and significant current pre-treatment calibration relationship with confidence limits (Fig. 5b) can be used later to compare the actual measured WS77 flow response with its expected flow response compared to WS80 for quantifying magnitude and significance of effects of longleaf pine restoration in near future. However, it should still be cautiously interpreted and applied if frequencies of extreme events, like the one assumed as the outlier in this study, continue to increase as shown by regional studies across the southeastern region (Ingram, Dow, Carter, \& Anderson, 2013).

\section{CONCLUSIONS}

This study evaluated recent nine years (2011-2019) of pre-treatment hydro-climatic data based streamflow (runoff) and its calibration relationships against those from pre-hurricane Hugo (1969-1978) and post-Hugo (2004-2011) periods since the hydrologic recovery for long-term paired watersheds (155 ha, WS77- treatment and 160 ha, WS80 - control) designated for longleaf pine (LLP) restoration project at Santee Experimental Forest on Atlantic Coastal Plain. Results revealed that the observed pre-treatment a) runoff pattern with WS77 > WS80 was maintained similar to both the pre- and post-Hugo periods and b) mean difference in monthly runoff between the two watersheds were not different $(\alpha=0.05)$ from the historic period but from the post-Hugo period, indicating complete runoff recovery to 1969-1978 period, supporting results of earlier study by Jayakaran et al. (2014). The consistently higher WS77 flow than the WS80 flow was attributed to the lower surface storage and higher hypsometric integral, a land morphological characteristic, than the WS80 with a potential for larger ET loss. In addition, the monthly flow calibration relationship without an extreme month (outlier) was not different from the 2004-2011 period but different from the 1969-1978 period, indicating influence of climatic regime of the periods. The regression relationship was also significant $(\alpha=0.05)$, predictable, and consistent, thereby providing the basis for quantifying post-treatment effects of the LLP restoration on water yield.

\section{REFERENCES}

Acharya, S., Jawitz, J. W., \& Mylavarapu, R. S. (2012). Analytical expressions for drainable and fillable porosity of phreatic aquifers under vertical fluxes from evapotranspiration and recharge. Water Resources Research , 48 (11). https://doi.org/10.1029/2012WR012043

Acreman, M., \& Holden, J. (2013). How wetlands affect floods.Wetlands , 33 (5), 773-786. https://doi.org/10.1007/s13157-013-0473-2

Alila, Y., Kuraś, P. K., Schnorbus, M., \& Hudson, R. (2009). Forests and floods: A new paradigm sheds light on age-old controversies. Water Resources Research , 45 (8). https://doi.org/10.1029/2008WR007207

Amatya, Chescheir, G. M., \& Skaggs, R. W. (1995). Hydrologic effects of the location and size of a natural wetland in an agricultural landscape.National Conference on "Versatility of Wetlands in the Agricultural Landscape," 477-488.

Amatya, D. M., Harrison, C. A., \& Trettin, C. C. (2016). Hydro-meteorologic Assessment of October 2015 Extreme Precipitation Event on Santee Experimental Forest Watersheds, South Carolina.Journal of South Carolina Water Resources , 3 (1), 19-30. https://www.fs.usda.gov/treesearch/pubs/54872

Amatya, D. M., \& Radecki-Pawlik, A. (2007). Flow dynamics of three experimental forested watersheds in coastal South Carolina (USA).Acta Sci.Pol. Form. Cir. , 6 (2), 3-17. http://www.formatiocircumiectus.actapol.net/pub/6_2_3.pdf

Amatya, D. M., Skaggs, R. W., \& Gregory, J. D. (1996). Effects of controlled drainage on the hydrology of drained pine plantations in the North Carolina coastal plain. Journal of Hydrology ,181 (1-4), 211-232. https://doi.org/10.1016/0022-1694(95)02905-2 
Amatya, Gregory, J. D., \& Skaggs, R. W. (2000). Effects of controlled drainage on storm event hydrology in a loblolly pine plantation. Journal of the American Water Resources Association ,36 (1), 175-190. https://doi.org/10.1111/j.1752-1688.2000.tb04258.x

Amatya, \& Harrison, C. A. (2016). Grass and forest potential evapotranspiration comparison using five methods in the Atlantic coastal plain. Journal of Hydrologic Engineering , 21 (5), 1-13. https://doi.org/10.1061/(ASCE)HE.1943-5584.0001341

Amatya, Miwa, M., Harrison, C. . A., \& Trettin, C. C. (2006). Hydrology and Water Quality of Two First Order Forested Watersheds in Coastal South Carolina. In S. Joseph (Ed.), American Society of Agricultural and Biological Engineers (p. 21).

Amatya, \& Skaggs, R. W. (2011). Long-term hydrology and water quality of a drained pine plantation in North Carolina. Transactions of the ASABE , 54 (6), 2087-2098.

Amatya, \& Trettin, C. C. (2019a). Santee Experimental Forest, Watershed 77: streamflow, water chemistry, water table, and weather data $\mid$ Ag Data Commons . Fort Collins, CO: Forest Service Research. https://doi.org/10.2737/RDS-2019-0033

Amatya, \& Trettin, C. C. (2019b). Long-Term Ecohydrologic Monitoring: A Case Study from the Santee Experimental Forest, South Carolina.The Journal of South Carolina Water Resources , 6 (6), 46-55. https://doi.org/10.34068/jscwr.06.05

Amatya, \& Trettin, C. C. (2007). Development of watershed hydrologic studies at Santee Experimental Forest, South Carolina. In M. J. Furniss, C. F. Clifton, \& K. L. Ronnenberg (Eds.), Forest Service National Earth Sciences Conference (pp. 180-190). Pacific Northwest Res. Station.

Amatya, Trettin, C., Panda, S., \& Ssegane, H. (2013). Application of LiDAR Data for Hydrologic Assessments of Low-Gradient Coastal Watershed Drainage Characteristics. Journal of Geographic Information System , 05 (02), 175-191. https://doi.org/10.4236/jgis.2013.52017

Amatya, Williams, T. M., Nettles, J. E., Skaggs, R. W., \& Trettin, C. C. (2019). Comparison of hydrology of two Atlantic coastal plain forests. Transactions of the ASABE , 62 (6), 1509-1529. https://doi.org/10.13031/trans.13387

Amoah, J. K. O., Amatya, D. M., \& Nnaji, S. (2013). Quantifying watershed surface depression storage: Determination and application in a hydrologic model. Hydrological Processes , 27 (17), 2401-2413. https://doi.org/10.1002/hyp.9364

Ares, M. G., Varni, M., \& Chagas, C. (2020). Runoff response of a small agricultural basin in the argentine Pampas considering connectivity aspects. Hydrological Processes , 34 (14), 3102-3119. https://doi.org/10.1002/hyp.13782

Binstock, D. A. (1987). Effects of a prescribed winter burn on anion nutrient budgets in the Santee Experimental Forest ecosystem.Duke University.

Bosch, J. M., \& Hewlett, J. D. (1982). A review of catchment experiments to determine the effect of vegetation changes on water yield and evapotranspiration. Journal of Hydrology , 55 (1-4), 3-23. https://doi.org/10.1016/0022-1694(82)90117-2

Brantley, S. T., Vose, J. M., Wear, D. N., \& Band, L. (2018). Potential of Longleaf Pine Restoration to Mitigate Water Scarcity and Sustain Carbon Sequestration: Planning for an Uncertain Future. In L. K. Kirkman \& S. B. Jack (Eds.), Ecological Restoration and Management of Longleaf Pine Forests (pp. 291-310). CRC Press - Taylor and Francis.

Bren, L. J., \& Lane, P. N. J. (2014). Optimal development of calibration equations for paired catchment projects. Journal of Hydrology , 519 (PA), 720-731. https://doi.org/10.1016/j.jhydrol.2014.07.059 
Brown, A. E., Zhang, L., McMahon, T. A., Western, A. W., \& Vertessy, R. A. (2005). A review of paired catchment studies for determining changes in water yield resulting from alterations in vegetation. Journal of Hydrology , 310 (1-4), 28-61. https://doi.org/10.1016/j.jhydrol.2004.12.010

Callahan, T. J., Vulava, V. M., Passarello, M. C., \& Garrett, C. G. (2012). Estimating groundwater recharge in lowland watersheds.Hydrological Processes , 26 (19), 2845-2855. https://doi.org/10.1002/hyp.8356

Chescheir, G. M., Skaggs, R. W., \& Amatya., D. M. (2009, October). Quantifying the Hydrologic Impacts of Afforestation in Uruguay: A Paired Watershed Study. XIII World Forestry Congress .

Clausen, J., \& Spooner, J. (1993). Paired watershed study design . U.S. Environmental Protection Agency, Office of Water.

Dai, Z., Trettin, C. C., \& Amatya, D. M. (2013). Effects of Climate Variability on Forest Hydrology and Carbon Sequestration on the Santee Experimental Forest in Coastal South Carolina . www.srs.fs.usda.gov

Ebel, B. A., Moody, J. A., \& Martin, D. A. (2012). Hydrologic conditions controlling runoff generation immediately after wildfire. Water Resources Research , 48 (3). https://doi.org/10.1029/2011WR011470

Eshleman, K. N., Pollard, J. S., \& O'Brien, A. K. (1994). Interactions between groundwater and surface water in a virginia coastal plain watershed. 1. Hydrological flowpaths. Hydrological Processes ,8 (5), 389-410. https://doi.org/10.1002/hyp.3360080503

Evaristo, J., \& McDonnell, J. J. (2019). Global analysis of streamflow response to forest management. Nature , 570 (7762), 455-461. https://doi.org/10.1038/s41586-019-1306-0

Friedman, J., Bohonak, A. J., \& Levine, R. A. (2013). When are two pieces better than one: fitting and testing OLS and RMA regressions.Environmetrics , 24 (5), 306-316. https://doi.org/10.1002/env.2213

Griffin, M. P., Callahan, T. J., Vulava, V. M., \& Williams, T. M. (2014). Storm-event flow pathways in lower coastal plain forested watersheds of the southeastern United States. Water Resources Research , 50 (10), 8265-8280. https://doi.org/10.1002/2014WR015941

Harder, S. V., Amatya, D. M., Callahan, T. J., Trettin, C. C., \& Hakkila, J. (2007). Hydrology and Water Budget for a Forested Atlantic Coastal Plain Watershed, South Carolina. Journal of the American Water Resources Association , 43 (3), 563-575. https://doi.org/10.1111/j.1752-1688.2007.00035.x

Harlin, J. M. (1978). Statistical moments of the hypsometric curve and its density function. Journal of the International Association for Mathematical Geology , 10 (1), 59-72. https://doi.org/10.1007/BF01033300

Hook, D. D., Buford, M. A., \& Williams, T. M. (1991). Impact of Hurricane Hugo on the South Carolina Coastal Plain Forest. Journal of Coastal Research , 291-300. https://doi.org/10.2307/25735422

Hornbeck, J. W., Adams, M. B., Corbett, E. S., Verry, E. S., \& Lynch, J. A. (1993). Long-term impacts of forest treatments on water yield: a summary for northeastern USA. Journal of Hydrology , 150 , 323-344.

Hu, L., Bao, W., Shi, P., Wang, J., \& Lu, M. (2020). Simulation of overland flow considering the influence of topographic depressions.Scientific Reports , 10 (1), 1-14. https://doi.org/10.1038/s41598-020-63001-y

Ingram, K. T., Dow, K., Carter, L., \& Anderson, J. A. (2013). Climate of the Southeast United States: Variability, change, impacts, and vulnerability. In Climate of the Southeast United States: Variability, Change, Impacts, and Vulnerability . Island Press-Center for Resource Economics. https://doi.org/10.5822/978-161091-509-0

Jayakaran, A. D., Williams, T. M., Ssegane, H., Amatya, D. M., Song, B., \& Trettin, C. C. (2014). Hurricane impacts on a pair of coastal forested watersheds: Implications of selective hurricane damage to forest structure and streamflow dynamics. Hydrology and Earth System Sciences , 18 (3), 1151-1164. https://doi.org/10.5194/hess-18-1151-2014 
Kelly, C. N., McGuire, K. J., Miniat, C. F., \& Vose, J. M. (2016). Streamflow response to increasing precipitation extremes altered by forest management. Geophysical Research Letters , 43 (8), 3727-3736. https://doi.org/10.1002/2016GL068058

Langbein, W. B. (1947). Topographic characteristics of drainage basins. Water Supply Paper, 125-157. https://doi.org/10.3133/wsp968C

Loftis, J. C., MacDonald, L. H., Streett, S., Iyer, H. K., \& Bunte, K. (2001). Detecting cumulative watershed effects: The statistical power of pairing. Journal of Hydrology , 251 (1-2), 49-64. https://doi.org/10.1016/S0022-1694(01)00431-0

Loheide, S. P., Butler, J. J., \& Gorelick, S. M. (2005). Estimation of groundwater consumption by phreatophytes using diurnal water table fluctuations: A saturated-unsaturated flow assessment. Water Resources Research , 41 (7), 1-14. https://doi.org/10.1029/2005WR003942

Luo, W. (2000). Quantifying groundwater-sapping landforms with a hypsometric technique. Journal of Geophysical Research: Planets ,105 (E1), 1685-1694. https://doi.org/10.1029/1999JE001096

Monteith, J. L. (1965). Evaporation and environment. Symposia of the Society for Experimental Biology, 19 , 205-234. https://europepmc.org/article/med/5321565

Olaya, V., \& Conrad, O. (2009). Geomorphometry in SAGA. InDevelopments in Soil Science (Vol. 33, Issue C). Elsevier Ltd. https://doi.org/10.1016/S0166-2481(08)00012-3

Perez-Pena, J. V., Azanon, J. M., \& Azor, A. (2009). CalHypso: An ArcGIS extension to calculate hypsometric curves and their statistical moments. Applications to drainage basin analysis in SE Spain. COMPUTERS AND GEOSCIENCES , 35 (6), 1214-1223.

R Development Core Team. (2015). A language and environment for statistical computing . R Foundation for Statistical Computing. http://www.r-project.org/

Rains, M. C., Leibowitz, S. G., Cohen, M. J., Creed, I. F., Golden, H. E., Jawitz, J. W., Kalla, P., Lane, C. R., Lang, M. W., \& Mclaughlin, D. L. (2016). Geographically isolated wetlands are part of the hydrological landscape. Hydrological Processes, 30 (1), 153-160. https://doi.org/10.1002/hyp.10610

Richter, D. . (1980). Effects of Water Quality and Nutrient Cycling in Forested Watersheds of the Santee Experimental Forest in South Carolina. Duke University.

Richter, D. D., Ralston, C. W., \& Harms, W. R. (1982). Prescribed fire: Effects on water quality and forest nutrient cycling. Science, 215 (4533), 661-663. https://doi.org/10.1126/science.215.4533.661

Robichaud, P. R. (2000). Fire effects on infiltration rates after prescribed fire in Northern Rocky Mountain forests, USA. Journal of Hydrology , 231 (1-4), 220-229. www.elsevier.com/locate/jhydrol

Samuelson, L. J., Stokes, T. A., \& Johnsen, K. H. (2012). Ecophysiological comparison of 50-yearold longleaf pine, slash pine and loblolly pine. Forest Ecology and Management, 274 (2012), 108-115. https://doi.org/10.1016/j.foreco.2012.02.017

SAS. (2006). Base SAS 9.1.3 procedures guide. SAS Institute, Inc.

Shelby, J. D., Chescheir, G. M., Skaggs, R. W., \& Amatya, D. M. (2005). Hydrologic and water-quality response of forested and agricultural lands during the 1999 extreme weather conditions in eastern North Carolina.Transactions of the American Society of Agricultural Engineers ,48 (6), 2179-2188.

Skaggs, R. W. (1978). A water management model for shallow water table soils. https://repository.lib.ncsu.edu/handle/1840.4/1618

Slattery, M. C., Gares, P. A., \& Phillips, J. D. (2006). Multiple modes of storm runoff generation in a North Carolina coastal plain watershed.Hydrological Processes , 20 (14), 2953-2969. https://doi.org/10.1002/hyp.6144 
Ssegane, H., Amatya, D. M., Chescheir, G. M., Skaggs, W. R., Tollner, E. W., \& Nettles, J. E. (2013). Consistency of Hydrologic Relationships of a Paired Watershed Approach. American Journal of Climate Change ,02 (02), 147-164. https://doi.org/10.4236/ajcc.2013.22015

Ssegane, H., Amatya, D. M., Muwamba, A., Chescheir, G. M., Appelboom, T., Tollner, E. W., Nettles, J. E., Youssef, M. A., Birgand, F., \& Skaggs, R. W. (2017). Calibration of paired watersheds: Utility of moving sums in presence of externalities. Hydrological Processes ,31 (20), 3458-3471. https://doi.org/10.1002/hyp.11248

Strahler, A. N. (1952). Hypsometric (area-altitude) analysis of erosional topography. Bulletin of the Geological Society of America , 63 (11), 1117-1142. https://doi.org/10.1130/00167606(1952)63[1117:HAAOET]2.0.CO;2

Todd, A. K., Buttle, J. M., \& Taylor, C. H. (2006). Hydrologic dynamics and linkages in a wetland-dominated basin. Journal of Hydrology ,319 (1-4), 15-35. https://doi.org/10.1016/j.jhydrol.2005.05.001

Tomer, M. D., \& Schilling, K. E. (2009). A simple approach to distinguish land-use and climate-change effects on watershed hydrology.Journal of Hydrology , 376 (1-2), 24-33. https://doi.org/10.1016/j.jhydrol.2009.07.029

Trettin, C. C., Amatya, D. M., Gaskins, A. H., Miniat, C. F., Chow, A., \& Callahan, T. (2019). Watershed response to longleaf pine restoration-application of paired watersheds on the Santee Experimental Forest. In J. S. Latimer, C. C. Trettin, D. D. Bosch, \& C. R. Lane (Eds.), Proceedings of the 6th Interagency Conference on Research in Watershed (Issue July 23-26, pp. 194-201). U.S. Department of Agriculture Forest Service, Southern Research Station.

Vivoni, E. R., Di Benedetto, F., Grimaldi, S., \& Eltahir, E. A. B. (2008). Hypsometric control on surface and subsurface runoff. Water Resources Research , 44 (12). https://doi.org/10.1029/2008WR006931

Vogel, R. M., \& Fennessey, N. M. (1995). Flow duration curves II: A review of applications in water resources planning. JAWRA Journal of the American Water Resources Association , 31 (6), 1029-1039. https://doi.org/10.1111/j.1752-1688.1995.tb03419.x

Walega, A., Amatya, D. M., Caldwell, P., Marion, D., \& Panda, S. (2020). Assessment of storm direct runoff and peak flow rates using improved SCS-CN models for selected forested watersheds in the Southeastern United States. Journal of Hydrology: Regional Studies , 27 , 100645. https://doi.org/10.1016/j.ejrh.2019.100645

Warton, D. I., Wright, I. J., Falster, D. S., \& Westoby, M. (2006). Bivariate line-fitting methods for allometry. Biological Reviews of the Cambridge Philosophical Society , 81 (2), 259-291. https://doi.org/10.1017/S1464793106007007

Williams, T. M. (2007). Evidence of runoff production mechanisms in low gradient coastal forested watersheds. 2007 ASABE Annual International Meeting . https://doi.org/10.13031/2013.22996

Wu, K., \& A. Johnston, C. (2008). Hydrologic comparison between a forested and a wetland/lake dominated watershed using SWAT.Hydrological Processes, 22 (10), 1431-1442. https://doi.org/10.1002/hyp.6695

\section{TABLES}

Table 1 General characteristics of the paired watersheds (WS77 and WS80)

\begin{tabular}{lll}
\hline Parameter & WS77 (Treatment) & WS80 (Control) \\
Location & $33.14^{\circ} \mathrm{N}, 79.77^{\circ} \mathrm{W}$ & $33.15^{\circ} \mathrm{N}, 79.8^{\circ} \mathrm{W}$ \\
Elevation (m a.m.s.l.) & $4.9-10.4$ & $3.5-10$ \\
Watershed size (ha) & 155 & 206 until 2001; 160 \\
Main channel length $(\mathrm{km})$ & 1.26 & 1.38 \\
Drainage density $\left(\mathrm{m}^{-1}\right)^{*}$ & 0.0037 & 0.0023
\end{tabular}


Wetland area, \%

Mean depressional storage

capacity, mm

Pre-Hugo period

Post-Hugo period

Pre-treatment period

* Total stream length calculate
$11 \quad 30$

$10( \pm 0.5) \quad 93( \pm 2.7)$

1969-1978 1969-1978

2004-2011 2004-2011

2011-2019 2011-2019

Table 2 Measured annual rainfall, flow, ET (rainfall - flow), and ROC and estimated PET for the WS77 and WS80 watersheds for 2011-2019 period

\begin{tabular}{llllllllll}
\hline Year & WS80 & WS80 & WS80 & WS80 & WS77 & WS77 & WS77 & WS77 & Forest \\
\hline & Rainfall, mm & Flow, mm & ROC & ET & Rainfall, mm & Flow, mm & ROC & ET & P-M PET, mm \\
2011 & 934 & 31 & 0.033 & 903 & 977 & 58 & 0.059 & 919 & 1351 \\
2012 & 1174 & 28 & 0.024 & 1146 & 1148 & 59 & 0.051 & 1089 & 1239 \\
2013 & 1433 & 219 & 0.153 & 1214 & 1502 & 350 & 0.233 & 1152 & 1017 \\
2014 & 1375 & 199 & 0.145 & 1176 & 1340 & 305 & 0.228 & 1035 & 1123 \\
2015 & 2171 & 967 & 0.445 & 1204 & 2146 & 948 & 0.442 & 1198 & 1098 \\
2016 & 1743 & 556 & 0.319 & 1187 & 1709 & 590 & 0.345 & 1119 & 1197 \\
2017 & 1443 & 217 & 0.150 & 1226 & 1555 & 421 & 0.271 & 1134 & 1177 \\
2018 & 1633 & 361 & 0.221 & 1272 & 1661 & 502 & 0.302 & 1159 & 1146 \\
2019 & 1381 & 201 & 0.146 & 1180 & 1429 & 361 & 0.253 & 1068 & 1200 \\
Average & $\mathbf{1 4 7 6}$ & $\mathbf{3 0 9}$ & $\mathbf{0 . 1 8 6}$ & $\mathbf{1 1 6 7 . 6}$ & $\mathbf{1 4 9 6}$ & $\mathbf{3 9 9}$ & $\mathbf{0 . 2 4 1 4}$ & $\mathbf{1 0 9 7 . 0}$ & $\mathbf{1 1 7 2}$ \\
Std Dev & 351.1 & 294.4 & 0.133 & 105.4 & 338.7 & 272.4 & 0.13 & 83.2 \\
COV & 0.24 & 0.95 & 0.71 & 0.09 & 0.23 & 0.68 & 0.52 & 0.08 & 0.08 \\
\hline
\end{tabular}

\section{FIGURE LEGENDS}

Figure 1 (a) Location map of the paired watersheds (WS77 -treatment and WS80 - control) and (b) their experimental layouts with existing monitoring stations, SSURGO soil types and forest land cover types on both the watersheds within Santee Experimental Forest (SEF) at Francis Marion National Forest, SC

Figure 2 Distributions of monthly flow (runoff) on WS80 and WS77 watersheds for the 2011-2019.

Figure 3 Difference in measured monthly flow (runoff) between the watersheds WS80 (control) and WS77 (treatment) for 2011-2019

Figure 4 Comparison of OLS (solid line), with its 95\% confidence intervals, and GM (broken line) regression lines for relationships between monthly flow (runoff) for WS77 and WS80 for 2011-2019 period

Figure 5 Regression relationship of (a) measured monthly flow (runoff) between WS80 (control) and WS77 (treatment) watersheds for the 2011-2019 period and (b) relationship without the October 2015 with an extreme storm event of October 3-4. Shown is a regression line for 2004-2011 period which is within the $95 \%$ confidence boundaries for the 2011-2019 mean

Figure 6 Regression relationship of 2011-2019 monthly flow (runoff) between WS77 and WS80 watersheds without outliers from mean \pm 1.5 Interquartile Range (IQR) with its $95 \%$ confidence boundaries. Shown are also the regression lines for pre- (1969-1978) and post-Hugo (2004-2011) periods

Figure 7 Daily flow duration curves for WS77 and WS80 for 2011-2019 period. Shown is enlarged plot for flow less than $20 \mathrm{~mm} \mathrm{day}^{-1}$

Figure 8 Measured (a) daily flow and daily cumulative rainfall and (b) hydrographs of June 8 and September 
5 storm events, both for WS77 and WS80, (c) daily water table depths on upland Well H (WS80) and Well J (WS77), and (d) daily water table depths for riparian Well D (WS80) and Well K (WS77) for the year 2019

Figure 9 Hypsometric curves for watersheds WS77 and WS80. Hypsometric integral less than 0.5 and positive density skewness are characteristics of landforms dominated by surface runoff rather than subsurface drainage (Vivoni et al., 2008)
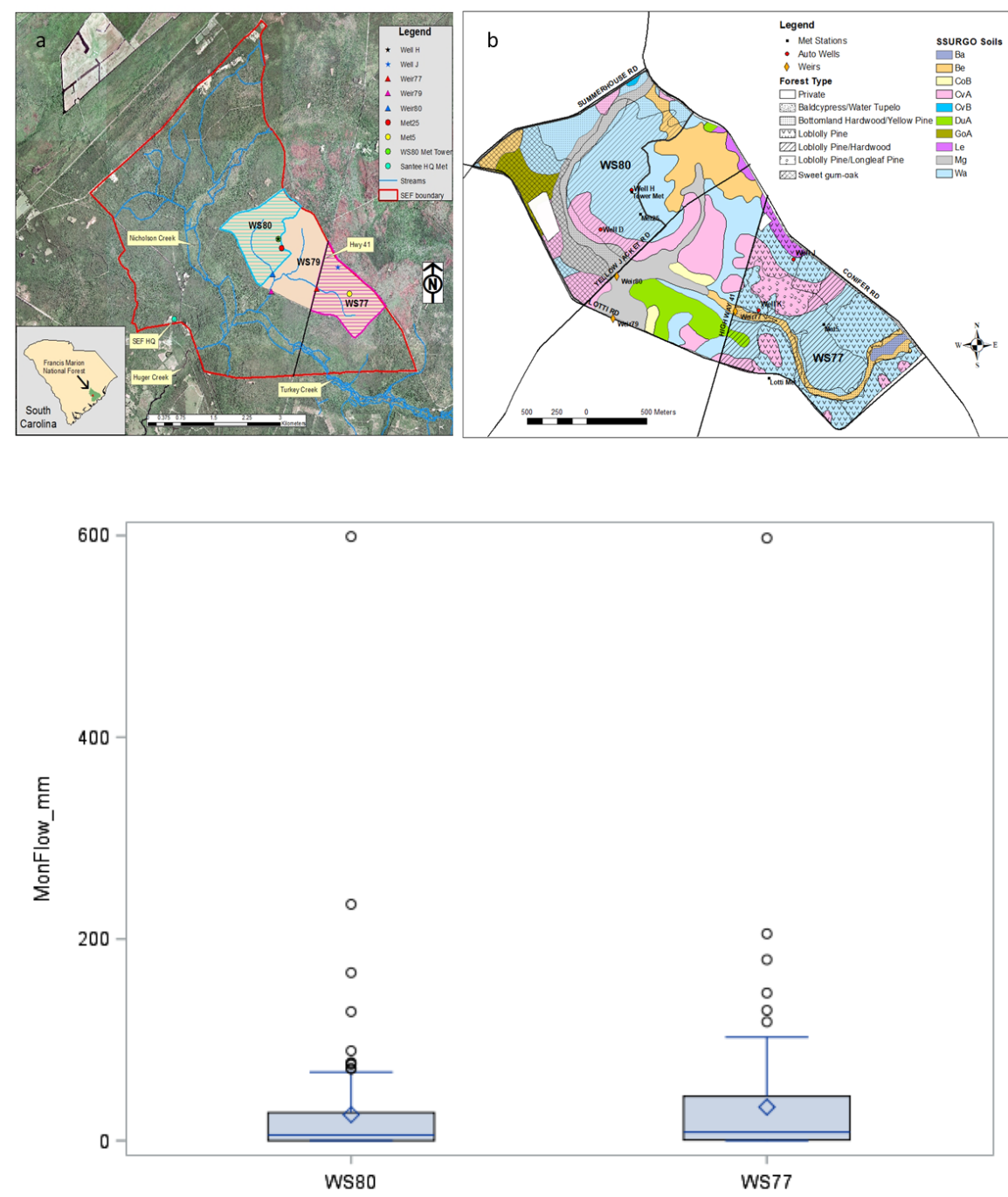

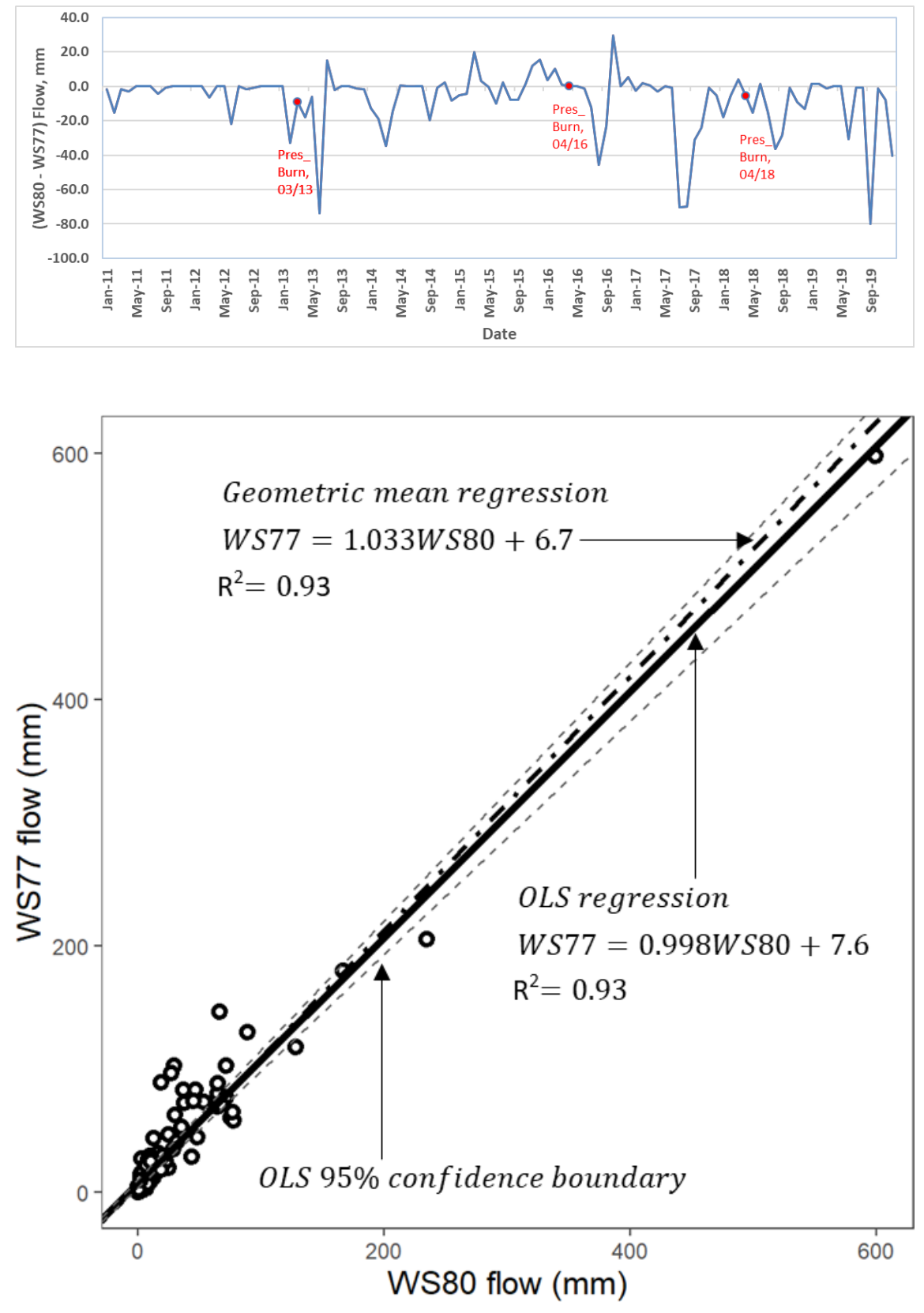

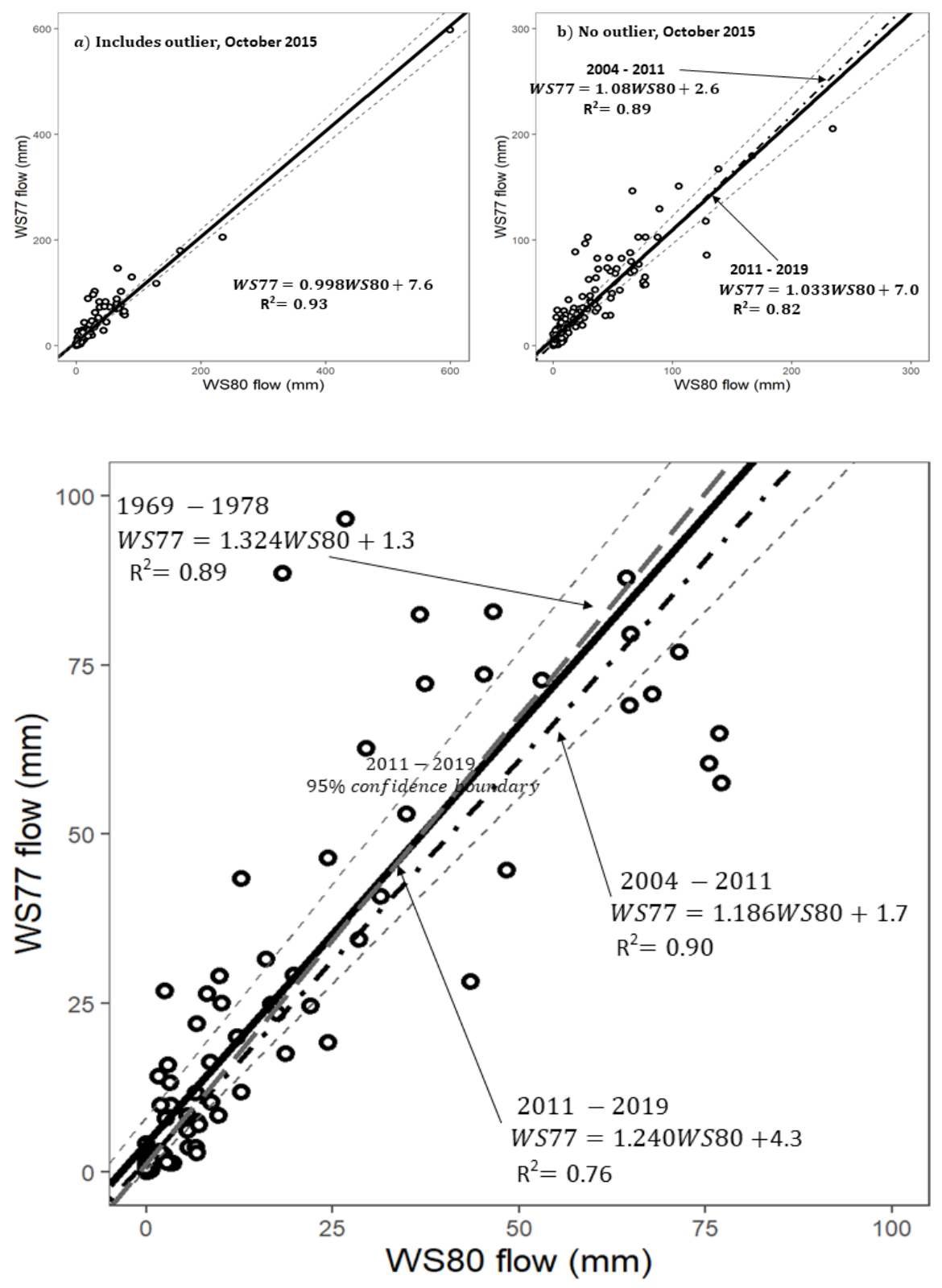

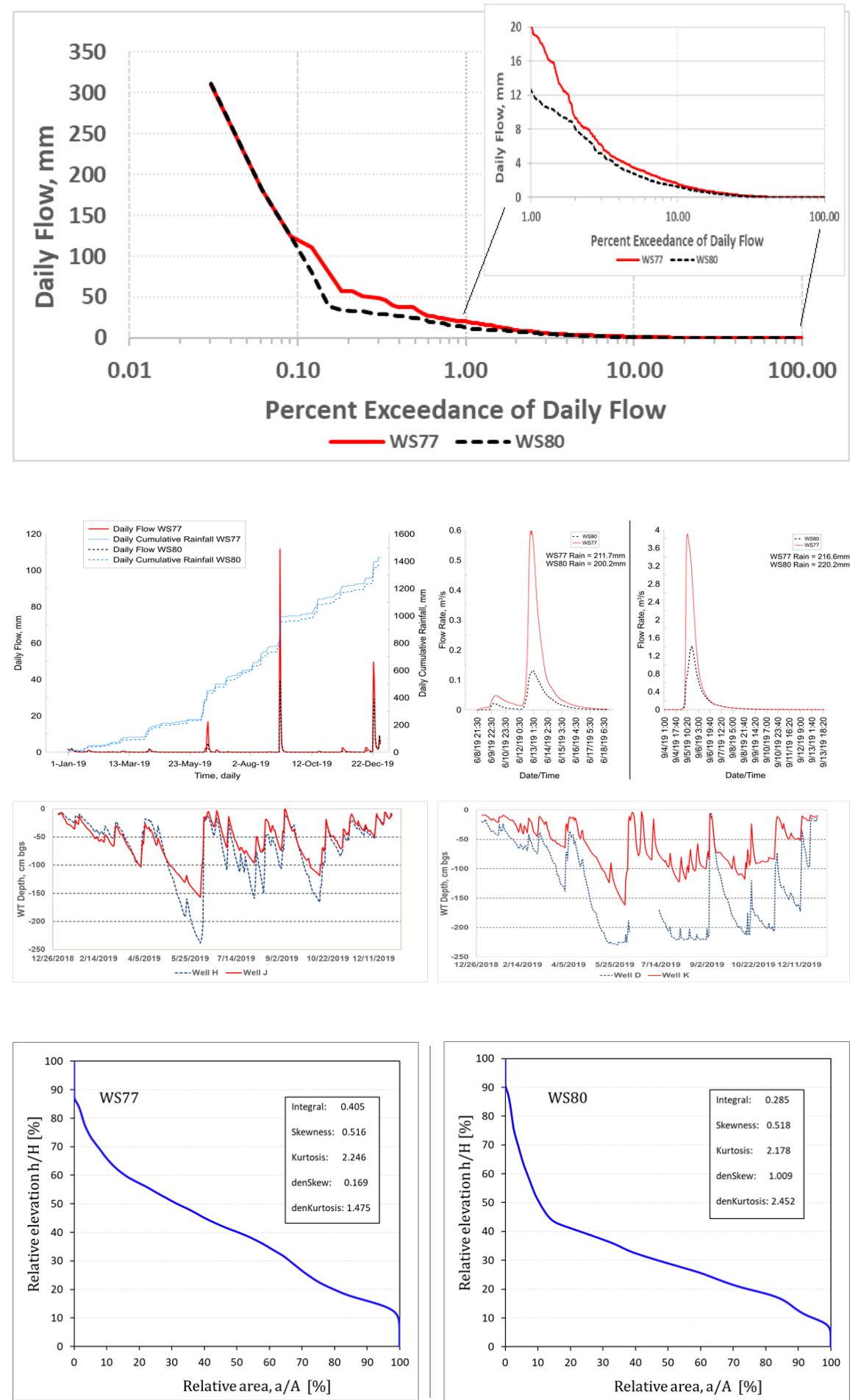

\section{Hosted file}

Tables.pdf available at https://authorea.com/users/364119/articles/484646-hydrologicrelationships-of-a-paired-coastal-watershed-on-the-santee-experimental-forest-forevaluating-watershed-scale-effects-of-longleaf-pine-restoration-on-water-yield 